\title{
房安恵美 学位論文審査要旨
}

$\begin{array}{cccc}\text { 主査 } & \text { 渡 } & \text { 邊 } & \text { 達 } \\ \text { 副主査 } & \text { 稲 } & \text { 垣 } & \text { 喜 } \\ \text { 同 } & \text { 中 } & \text { 島 } & \text { 健 }\end{array}$

\section{主論文}

Increased plasma substance P and CGRP levels, and high ACE activity in migraineurs during headache-free periods

(発作間欠期の片頭痛患者において血漿サブスタンスP、CGRP濃度は増加し、ACE活性は高い) (著者 : 房安恵美、古和久典、竹島多賀夫、中曾一裕、中島健二)

平成19年 Pain 掲載予定 


\section{学 位 論 文 要 旨}

\section{Increased plasma substance P and CGRP levels, and high ACE activity in migraineurs during headache-free periods}

（発作間欠期の片頭痛患者において血漿サブスタンスP、CGRP濃度は増加し、ACE活性は 高()

片頭痛の病態は、様々な研究が行われているものの、その詳細は依然として不明である。 今日広く受け入れられている三叉神経血管説では、不明の刺激が硬膜血管周囲三叉神経を活 性化し、サブスタンスP (SP) やカルシトニン遺伝子関連ペプチド(CGRP) などの血管作動性神経 ペプチドが放出され、神経原性炎症が引き起こされる。炎症が順行性および逆行性に三叉神 経領域に拡大し、侵害刺激として順行性に三叉神経核を経て大脳皮質へと伝達され、痛みを 発現する。

本研究は発作間欠期においてSP、CGRP濃度、及びSPの代謝に関与しているアンギオテンシ ン I 変換酵素 (ACE) の酵素活性を同一検体で測定し、健常対照者と比較し、これらの物質の相 関を検討することを目的としたものである。

\section{方 法}

41名の前兆のある片頭痛患者 (MA)、54名の前兆のない片頭痛患者 (MO)、52名の頭痛を有し ない健常対照者を対象とした。国際頭痛学会診断基準により片頭痛の診断を行った。

発作間欠期において安静時に肘静脈より採血を行い、血漿を分離後、 $-30^{\circ} \mathrm{C} て ゙$ 測定まで保存 した。SP、CGRPはC18カラムにて前処理を行い、EIAキットを用いて測定した。ACE活性はUV 比法を用いて測定した。片頭痛群と健常対照者群の比較にはMann-Whitney U検定、MA、MO、 健常対照者の比較には一元配置分散分析を用い、これらの值の相関はPearsonの相関係数を用 いて統計学的検討を行った。

\section{結 果}

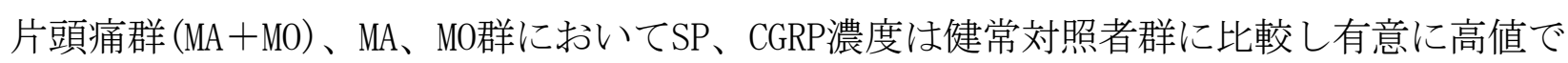
あった。MA群においてACE活性はMO群、健常対照者群と比較し有意に高值であった。

すべての対象において、SP、CGRP濃度は有意な正の相関関係を認め、SP濃度とACE活性との 間では弱いが有意な正の相関関係を認めた。一方、CGRP濃度とACE活性においては相関を認め なかった。 


\section{考 察}

この研究は成人片頭痛患者において、SPとCGRP濃度を検討した初めての研究である。

発作間欠期においてSPやCGRPが上昇していることは、神経支配下での血管収縮や拡張反応 性の異常をきたしている可能性が考えられる。いくつかの研究により発作間欠期における二 酸化炭素に対する脳血管反応性の上昇、一酸化窒素に対する過敏性が示されている。つまり、 二酸化炭素吸入による脳血流速度増加が生じやすいこと、一酸化窒素にて頭痛が誘発されや すいこと、血管の拡張反応性の上昇が報告されている。さらに、発作間欠期におけるSP、CGRP の上昇は、次の片頭痛発作に対する準備状態である可能性も考えられる。すおなち、これら の神経ペプチドの上昇は、硬膜血管拡張を引き起こすための閾值を下げており、そのことに より片頭痛発作が引き起こされている可能性が推定される。

血漿ACE活性は遺伝的要因が強く影響しており、ACE遺伝子にある

insertion (I)/deletion (D) 多型はACE濃度と関連している。ACE活性はD/D多型でより高值であ り、MAにおいてD/D多型の頻度が高いことがすでに報告されている。MAにておいてACE活性が 高值であるという今回の結果は過去の報告と矛盾しないと考えられた。

SP とCGRPは三叉神経感覚線維においてしばしば共存しており、三叉神経の活性化によりこ れらの神経ペプチドの放出が引き起こされる。また、CGRPはSPの働きを増強することも示唆 されている。さらにCGRPとSPには半減期の違いがあることから、SPとCGRPにおいて弱いなが らも相関が認められたと考えた。

SPはneutral endopeptidase (NEP)、ACEを含め多数の酵素により代謝される。本来、ACE活 性が高ければSP濃度はより低值となるべきだが、何らかの代償機構、あるいはSP濃度の上昇 によりACE活性が誘導されることにより、SP濃度とACE活性が正の相関を示したと考えた。

今回の研究ではCGRP濃度とACE活性の相関はみられなかった。CGRPの代謝にはNEPが最も重 要であるといういくつかの報告もあることから、ACEはCGRPの代謝において重要ではない可能 性が考えられた。

\section{結 論}

片頭痛発作間欠期においてSP、CGRP濃度は高值であり、前兆のある片頭痛患者の発作間欠 期においてACE活性は有意に高值であった。今回の結果からSP、CGRP、ACEは片頭痛の病態に 関与しており、相互作用を有している可能性が示唆された。相互作用を考慮したSPとCGRPの 両方に作用寸る薬剤が片頭痛予防に有効である可能性が示唆される。本研究では発作期での 検討は行っていないが、この点についてさらなる研究が必要である。 